\title{
Deep investigation on inorganic fraction of atmospheric PM in Mediterranean area by neutron and photon activation analysis
}

\author{
Pasquale Avino ${ }^{1 *}$, Geraldo Capannesi ${ }^{2}$, Maurizio Manigrasso ${ }^{1}$, Alberto Rosada ${ }^{2}$ and Mario Vincenzo Russo ${ }^{3}$
}

\begin{abstract}
Background: Anthropogenic activities introduce materials increasing levels of many dangerous substances for the environmental quality and being hazardous to human health. Major attention has been given to those elements able to alter the environment and endanger human health.

The airborne particulate matter pollutant is considered one of the most difficult task in environmental chemistry for its complex composition and implications complicating notably the behavior comprehension. So, for investigating deeply the elemental composition we used two nuclear techniques, Neutron Activation Analysis and Photon Activation Analysis, characterized by high sensitivity, precision and accuracy. An important task has been devoted to the investigation of Quality Control (QC) and Quality Assurance (QA) of the methodology used in this study. This study was therefore extended as far back as possible in time (from 1965 until 2000) in order to analyze the trend of airborne concentration of pollutant elements in connection with the industrial and lifestyle growth during the entire period.

Results: Almost all the elements may be attributed to long-range transport phenomena from other natural and/or anthropogenic sources: this behavior is common to all the periods studied even if a very light decreasing trend can be evidenced from 1970 to 2002. Finally, in order to investigate a retrospective study of elements in PM10 and their evolution in relationship with the natural or anthropogenic origins, we have investigated the Enrichment Factors. The study shows the EF trends for some elements in PM10 during four decades.

Conclusions: The two nuclear techniques have allowed to reach elevated sensibility/accuracy levels for determining elements at very low concentrations (trace and ultra-trace levels). The element concentrations determined in this study do not basically show a significant level of attention from a toxicological point of view.
\end{abstract}

Keywords: Element, PM10, PM2.5, Atmosphere, Urban air, Enrichment factor, INAA, IPAA

\section{Background}

One of the most interesting and difficult task in environmental chemistry is the investigation of the inorganic chemical composition of the particulate matter. Different reasons are the basis of this consideration: for instance, the very low levels of some elements (e.g., $\mathrm{Cd}, \mathrm{Hg}$, Se, at ultra-trace levels), the sampling collection which is more representative as possible, the availability of analytical methods (expecially, no-destructive but really sensitive methodologies) [1-11].

\footnotetext{
* Correspondence: p.avino@inail.it

'DIPIA, INAIL settore Ricerca, Certificazione e Verifica, Via IV Novembre 144, Rome 00187, Italy

Full list of author information is available at the end of the article
}

The element distribution in air is fundamentally determined by resuspension from soil and water of various substances of natural and/or artificial origin, by their type of circulation due to the meteorological events and by the chemical element behavior. Anthropogenic activities introduce species increasing levels of many substances which may endanger the environmental quality and represent a hazard to human health. Major attention has been given to those elements able to alter the environment and endanger human health.

The issue regarding the determination of trace elements in airborne particulate have a preeminent position due to the presence of some toxic elements (e.g., $\mathrm{Cd}, \mathrm{Hg}$ and $\mathrm{Pb}$ ): further, the airborne particulate matter enters
(C) Chemistry Central

C 2013 Avino et al.; licensee Chemistry Central Ltd. This is an open access article distributed under the terms of the Creative Commons Attribution License (http://creativecommons.org/licenses/by/2.0), which permits unrestricted use, distribution, and reproduction in any medium, provided the original work is properly cited. 
into the climate global change problem, giving place to increasing global levels that may affect widely the biological systems.

The very complex composition and implications of the airborne particulate matter pollutant $\mathrm{PM}_{10}$ and, expecially, the distribution and multielemental composition of the fine fraction (i.e., particles with diameter $<2.5 \mu \mathrm{m}$, $\mathrm{PM}_{2.5}$ ), complicate notably the behavior comprehension. The evaluation of background levels due to natural pathways of circulation, seems the preliminar action to be undertaken. This study was therefore extended as far back as possible in time (from the seventies until nowdays) in order to analyze the trend of airborne concentration of pollutant elements in connection with the industrial and lifestyle growth during the entire period.

Instrumental nuclear techniques are widely used in this field [12] as they represent the most reliable method for analyzing trace and/or ultra-trace elements in air particulate $\mathrm{PM}_{10}$ and $\mathrm{PM}_{2.5}$. Instrumental Neutron Activation Analysis (INAA) as well Instrumental Photon Activation Analysis (IPAA) have been employed in this work to measure interesting toxicologically elements. INAA is not universally applicable with regard to the elements that can be determined, as the technique does not have sufficient sensitivity for $\mathrm{Ca}, \mathrm{Ti}, \mathrm{Sr}$ and $\mathrm{Zr}$ for example, and $\mathrm{Nb}, \mathrm{Pb}, \mathrm{Tl}$ and $\mathrm{Y}$ are impossible to measure. Similarly, determination of some elements is complicated due to interfering nuclear reactions or from the products of uranium fission (samples with elevated U concentration) $[13,14]$. An useful complementary method to INAA is Instrumental Photon Activation Analysis (IPAA), which enables the determination of the above elements. The IPAA method has been utilised on a much smaller scale in analytical field [15,16]. In IPAA, the nuclei can be activated through photonuclear process: in fact, contrary to INAA based mainly on the neutron capture reaction $(\mathrm{n}, \gamma)$, PAA employs photonuclear reactions, particularly the $(\gamma, \mathrm{n})$ reaction [17]. Activation is induced by high energy photons having energy of at least $10 \mathrm{MeV}$. The photonuclear reaction data of the elements require around $30 \mathrm{MeV}$ for activation energy. For analytical data interpretation, IPAA results have been considered only for the elements that cannot be determined and/or are difficult to determine by INAA [18-27], and for which IPAA provides results of comparable or better quality. Determination of other elements, such as $\mathrm{Mn}, \mathrm{Rb}, \mathrm{Cs}, \mathrm{Ba}, \mathrm{Ce}, \mathrm{U}$ by IPAA should be considered of subsidiary value because INAA is more sensitive. Finally, as reported in literature [28], IPAA is not as commonly used as INAA but possibilities for element determination by both INAA and IPAA depend strongly on the matrix composition.

In particular, over $\mathrm{As}, \mathrm{Cd}, \mathrm{Cr}, \mathrm{Hg}, \mathrm{Pb}, \mathrm{Sb}$ and $\mathrm{Zn}$, i.e. metals considered of greater health concern, other elements, e.g. Au, Cs, La, Mo, Sc, Se, Sm, Th, W, were measured.

\section{Results and discussion}

\section{Quality control}

Table 1 shows the analytical quality control performed on a Standard Reference Material (SRM). This control was performed through an intercomparison campaign for 14 elements promoted by the International Atomic Energy Agency (IAEA) on air filter samples among different worldwide laboratories (130) using both spectrochemical (colorimetry, fluorescence, $x$-ray fluorescence, infrared spectrometry, atomic absorption and emission spectrometry, ICP-AES, ICP-MS), electrochemical (polarography, voltammetry) and nuclear (INAA, IPAA, isotopic dilution, beta counting) analytical techniques. For each element our values ("measured value") and the "certified value" are reported: the third column ("average value") represents the value averaged among all the determinations performed by different laboratories interested in the round-robin. As it can be noted, the agreement between our and the real value is quite good except for some elements such as $\mathrm{Ba}, \mathrm{U}$ and $\mathrm{Zn}$. For $\mathrm{Ba}$ and $U$ this discrepancies can be due to the difficulty to analyze such kind of elements even if for Ba our "measured value" (43.4 \pm 0.5$)$ and the "average value" (39.05 \pm 15.62) are quite similar. For $\mathrm{Zn}$ the situation is little bit different. The "measured value" (132 $\left.\pm 18 \mu \mathrm{g} \mathrm{g}^{-1}\right)$ falls out the certified value $\left(152 \mu \mathrm{g} \mathrm{g}^{-1}\right)$ whereas it is in "average value" range $\left(141 \pm 16 \mu \mathrm{g} \mathrm{g}^{-1}\right)$ : the two-tailed $\mathrm{P}$ value is less than 0.001 and, by conventional criteria, this difference is considered to be statistically significant.

Table 1 Results of the Quality Control on IAEA air filter samples $\left(\mu \mathbf{g ~ g}^{-1}\right)$

\begin{tabular}{ccccc}
\hline Element & Measured value & $\begin{array}{c}\text { Certified value } \\
\text { mean } \pm \text { s.d. }\end{array}$ & \multicolumn{2}{c}{ Average value } \\
\cline { 4 - 5 } $\mathrm{As}$ & $4.9 \pm 0.5$ & 5.6 & 4.59 & 43 \\
$\mathrm{Au}$ & $1.26 \pm 0.10$ & 1.15 & 1.06 & 21 \\
$\mathrm{Ba}$ & $43.4 \pm 0.5$ & 53.8 & 39.05 & 40 \\
$\mathrm{Cd}$ & $10.6 \pm 1.0$ & 9.96 & 9.8 & 18 \\
$\mathrm{Co}$ & $1.3 \pm 0.1$ & 1.12 & 1.18 & 38 \\
$\mathrm{Cr}$ & $4.7 \pm 0.8$ & 5.6 & 4.8 & 13 \\
$\mathrm{Cu}$ & $51.6 \pm 0.5$ & 48.8 & 44.8 & 16 \\
$\mathrm{Fe}$ & $193 \pm 17$ & 207.9 & 200.1 & 8 \\
$\mathrm{Mn}$ & $31.2 \pm 1.0$ & 31.9 & 30.1 & 14 \\
$\mathrm{Mo}$ & $1.26 \pm 0.2$ & 1.14 & 1.56 & 70 \\
$\mathrm{Se}$ & $1.01 \pm 0.10$ & 1.06 & 1.01 & 11 \\
$\mathrm{U}$ & $0.78 \pm 0.10$ & 1.02 & 0.99 & 14 \\
$\mathrm{~V}$ & $8.04 \pm 0.35$ & 8.00 & 7.2 & 16 \\
$\mathrm{Zn}$ & $132 \pm 18$ & 152 & 141 & 12 \\
\hline
\end{tabular}

The "measured value" is the average of seven determinations on seven different replicates. s.d.: standard deviation. 


\section{Particulate matter results}

Average concentration values, minimum and maximum levels and standard deviation of the elements determined in the $\mathrm{PM}_{2.5}$ fraction are shown in Table 2 whereas the correlation coefficients of the analyzed elements are reported in Table 3. It should be noted that many elements cannot be possible to determine in these samples: the main reasons depend on both the granulometric size fraction, $2.5 \mu \mathrm{m}$, as just reported in literature [9], and the very low levels reached by some elements (e.g., Nd is below LOD). Basically, the concentration levels of the elements are very low. There is only a very significant correlation between $\mathrm{Br}$ and $\mathrm{Sb}$ (correlation coefficient 0.95 ). The $\mathrm{Br}$ presence in air is essentially attributed to natural (e.g., marine aerosol) and anthropogenic (e.g., autovehicular traffic [7] sources. This high correlation coefficient with $\mathrm{Sb}$ hypothesizes a strong anthropogenic contribution to the Br level. Furthermore, it

Table 2 Synoptic table (mean value, min-max values and standard deviation) of elements concentration ( $\mathrm{ng} \mathrm{m}^{-3}$ ) determined in $\mathbf{P M}_{2.5}$ in downtown Rome (LOD: limit of detection; * expressed as $\mathrm{pg} \mathrm{m}^{-3}$; ${ }^{* *}$ expressed as $\mathrm{\mu g} \mathrm{m}^{-3}$ )

\begin{tabular}{|c|c|c|c|}
\hline \multirow[t]{2}{*}{ Element } & \multicolumn{3}{|c|}{ PM2.5 } \\
\hline & Mean & Min-Max & St. dev. \\
\hline As & 1.06 & $0.121-2.76$ & 0.044 \\
\hline $\mathrm{Au}$ & 0.009 & $0.000-0.050$ & 0.012 \\
\hline $\mathrm{Ba}$ & 3.76 & $1.91-6.45$ & 2.38 \\
\hline $\mathrm{Br}$ & 17.1 & $3.20-50.4$ & 13.9 \\
\hline $\mathrm{Ce}$ & 0.130 & $0.033-0.335$ & 0.089 \\
\hline Co & 0.167 & $0.077-0.331$ & 0.065 \\
\hline $\mathrm{Cr}$ & 3.03 & $1.29-6.40$ & 1.30 \\
\hline Cs & 0.047 & $0.004-0.124$ & 0.037 \\
\hline $\mathrm{Eu}^{*}$ & 1.14 & $1.12-1.16$ & 0.029 \\
\hline $\mathrm{Fe}^{* *}$ & 0.074 & $0.005-0.212$ & 0.059 \\
\hline $\mathrm{Hf}$ & 0.018 & $0.006-0.032$ & 0.010 \\
\hline $\mathrm{Hg}$ & 0.818 & $0.195-2.12$ & 0.655 \\
\hline $\mathrm{La}^{*}$ & 22.6 & $8.73-53.3$ & 10.5 \\
\hline Mo & 0.748 & $0.017-3.04$ & 0.699 \\
\hline $\mathrm{Nd}$ & $<\mathrm{LOD}$ & & \\
\hline $\mathrm{Ni}$ & 3.54 & $1.91-5.82$ & 1.45 \\
\hline $\mathrm{Rb}$ & 1.82 & $0.416-3.74$ & 1.07 \\
\hline $\mathrm{Sb}$ & 3.60 & $0.690-12.6$ & 3.24 \\
\hline $\mathrm{Sc}^{*}$ & 3.14 & $0.208-7.49$ & 2.41 \\
\hline Se & 0.567 & $0.116-1.55$ & 0.415 \\
\hline $\mathrm{Sm}^{*}$ & 3.88 & $0.208-7.78$ & 2.13 \\
\hline Th & 0.027 & $0.007-0.041$ & 0.010 \\
\hline W & 0.636 & $0.062-2.86$ & 0.682 \\
\hline $\mathrm{Yb}$ & 0.011 & $0.003-0.027$ & 0.007 \\
\hline $\mathrm{Zn}$ & 58.0 & $4.78-252$ & 61.3 \\
\hline
\end{tabular}

can be noted a wide scattering between the correlation coefficients: only As, $\mathrm{Co}, \mathrm{Fe}, \mathrm{Sc}, \mathrm{Sb}$, Se are highly correlated $(0.7<$ correlation coefficient $<0.9$, marked in bold in Table 3) whereas $\mathrm{Au}, \mathrm{Ba}, \mathrm{Br}, \mathrm{Ce}, \mathrm{Cr}, \mathrm{Cs}, \mathrm{La}, \mathrm{Sm}$ result scarcely correlated. This behavior can be expected considering the chemical-physical properties of the elements and the granulometric size $(<2.5 \mu \mathrm{m})$, as previously evidenced in previous papers $[7,9]$.

In Tables 4 and 5 are reported for each element both the summer and winter average levels as well as the maximum and minimum values for each season measured in $\mathrm{PM}_{10}$ samples by INAA and IPAA. The samples were collected in outskirt of Rome and downtown [29], respectively, during summer and winter period. It may be noted that elements of anthropogenic origin show winter concentration levels higher than the summer ones, probably owing to an enhanced production in the winter period; in contrast elements of natural origin show summer concentration levels higher than the winter ones, possibly as a consequence of an increased resuspension of soil matter in summer. The values in the two tables are quite similar for some elements whereas difference distributions between the two time periods are evident. This last issue influences the element behavior in atmosphere.

As a very simple approach for understanding the element behavior, they were grouped into three categories according to the value of the ratio (R) of summer to winter average levels (Table 6). The first group includes elements whose $\mathrm{R}$ is greater than 2 ; the second group elements whose $\mathrm{R}$ is less than 2 but greater than 0.5 ; the last group includes elements whose $\mathrm{R}$ is less than 0.5 . Looking at the table, it can be noted a ratio difference between the elements determined in outskirt and in downtown: only 6 elements, such as $\mathrm{Al}, \mathrm{Br}, \mathrm{K}, \mathrm{Na}, \mathrm{Ti}, \mathrm{U}$, show $\mathrm{R}>2$ in samples collected in downtown whereas 20 elements, i.e. $\mathrm{Al}, \mathrm{Ba}, \mathrm{Ca}, \mathrm{Ce}, \mathrm{Cs}, \mathrm{Eu}, \mathrm{Fe}, \mathrm{Hf}, \mathrm{K}, \mathrm{La}$, $\mathrm{Mg}, \mathrm{Na}, \mathrm{Rb}, \mathrm{Sc}, \mathrm{Ta}, \mathrm{Tb}, \mathrm{Th}, \mathrm{Ti}, \mathrm{U}, \mathrm{Zr}$, show ratios $>2$ in samples collected in outskirt.

Elements of natural origin are only found in the first group, while elements of both natural and anthropogenic origin are present in the second group. The third group includes only pollutant elements $(\mathrm{Cd}, \mathrm{Cr}, \mathrm{Mo}$, $\mathrm{Ni}, \mathrm{Pb}, \mathrm{V}, \mathrm{Zn})$.

An intersting considerations, coming from the data analysis, are obviously strictly related to the general meteorological characteristics of Italy and therefore contain some peculiarity. If they are compared to similar results obtained in other countries under different meteorological conditions, it can be seen that they agree fairly well for the pollutant elements, whereas for most elements of natural origin there are sensible differences that may be related to the geomorphological and meteorological characteristics. In fact, the higher values 
Table 3 Correlation coefficients for the trend of concentrations of analyzed elements present in $\mathrm{PM}_{2.5}$

\begin{tabular}{|c|c|c|c|c|c|c|c|c|c|c|c|c|c|c|c|c|c|c|c|c|c|}
\hline As & $\mathrm{Au}$ & $\mathrm{Ba}$ & $\mathrm{Br}$ & $\mathrm{Ce}$ & Co & $\mathrm{Cr}$ & Cs & $\mathrm{Fe}$ & $\mathrm{Hf}$ & $\mathrm{Hg}$ & La & Mo & $\mathrm{Rb}$ & $\mathrm{Sb}$ & Sc & $\mathrm{Se}$ & $\mathrm{Sm}$ & Th & w & $\mathrm{Zn}$ & \\
\hline & \multirow[t]{20}{*}{0.25} & -0.80 & 0.85 & 0.37 & 0.85 & 0.65 & 0.50 & 0.80 & 0.51 & -0.35 & 0.70 & 0.50 & 0.39 & 0.83 & 0.40 & 0.80 & 0.55 & 0.20 & -0.19 & 0.37 & As \\
\hline & & -0.97 & 0.58 & 0.51 & 0.35 & 0.06 & 0.54 & 0.33 & 0.73 & 0.35 & 0.01 & 0.10 & 0.77 & 0.48 & 0.01 & 0.56 & 0.08 & -0.32 & -0.19 & 0.16 & $\mathrm{Au}$ \\
\hline & & & -0.97 & -1.00 & -0.98 & -0.95 & -0.89 & -0.65 & -1.00 & -0.43 & -0.81 & -0.91 & -1.00 & -0.99 & 0.62 & -0.94 & -0.98 & -0.98 & -0.11 & -0.65 & $\mathrm{Ba}$ \\
\hline & & & & 0.61 & 0.87 & 0.54 & 0.57 & 0.83 & 0.86 & -0.22 & 0.57 & 0.23 & 0.68 & 0.95 & 0.35 & 0.89 & 0.50 & 0.16 & -0.17 & 0.58 & $\mathrm{Br}$ \\
\hline & & & & & 0.51 & 0.39 & 0.29 & 0.46 & 0.59 & 0.15 & 0.41 & 0.15 & 0.77 & 0.64 & 0.05 & 0.66 & 0.10 & -0.32 & -0.14 & 0.50 & $\mathrm{Ce}$ \\
\hline & & & & & & 0.69 & 0.53 & 0.81 & 0.63 & -0.22 & 0.72 & 0.24 & 0.78 & 0.90 & 0.35 & 0.86 & 0.53 & 0.25 & 0.10 & 0.60 & Co \\
\hline & & & & & & & 0.09 & 0.67 & -0.13 & -0.34 & 0.66 & 0.43 & 0.45 & 0.61 & 0.29 & 0.71 & 0.45 & 0.04 & -0.24 & 0.44 & $\mathrm{Cr}$ \\
\hline & & & & & & & & 0.44 & 0.83 & 0.15 & 0.47 & 0.19 & 0.72 & 0.60 & 0.13 & 0.43 & 0.19 & 0.18 & -0.20 & 0.05 & Cs \\
\hline & & & & & & & & & 0.39 & -0.38 & 0.73 & 0.14 & 0.57 & 0.85 & 0.65 & 0.79 & 0.72 & 0.27 & -0.29 & 0.50 & $\mathrm{Fe}$ \\
\hline & & & & & & & & & & 0.56 & 0.13 & 0.48 & -0.05 & 0.82 & 0.26 & 0.73 & 0.46 & 0.26 & 0.01 & 0.55 & $\mathrm{Hf}$ \\
\hline & & & & & & & & & & & -0.34 & -0.16 & 0.22 & -0.17 & -0.41 & -0.21 & -0.40 & -0.37 & -0.03 & -0.04 & $\mathrm{Hg}$ \\
\hline & & & & & & & & & & & & 0.30 & 0.49 & 0.64 & 0.42 & 0.60 & 0.55 & 0.41 & -0.15 & 0.26 & La \\
\hline & & & & & & & & & & & & & 0.36 & 0.27 & -0.07 & 0.40 & 0.12 & -0.31 & -0.21 & 0.03 & Mo \\
\hline & & & & & & & & & & & & & & 0.79 & -0.34 & 0.76 & -0.29 & -0.57 & -0.02 & 0.37 & $\mathrm{Rb}$ \\
\hline & & & & & & & & & & & & & & & 0.41 & 0.87 & 0.53 & 0.15 & -0.13 & 0.68 & $\mathrm{Sb}$ \\
\hline & & & & & & & & & & & & & & & & 0.24 & 0.89 & 0.47 & -0.11 & 0.44 & Sc \\
\hline & & & & & & & & & & & & & & & & & 0.44 & -0.06 & -0.28 & 0.53 & Se \\
\hline & & & & & & & & & & & & & & & & & & 0.39 & -0.09 & 0.50 & Sm \\
\hline & & & & & & & & & & & & & & & & & & & 0.24 & 0.17 & Th \\
\hline & & & & & & & & & & & & & & & & & & & & 0.07 & w \\
\hline
\end{tabular}


Table 4 Seasonal element concentrations (average, min and max levels expressed as $\mathrm{ng} \mathrm{m}^{-3}$; a: $\mathrm{pg} \mathrm{m}^{-3}$ ) in $\mathrm{PM}_{10}$ determined by INAA and IPAA in atmospheric particulate sampled in outskirt of Rome

\begin{tabular}{|c|c|c|c|c|c|c|}
\hline \multirow[t]{2}{*}{ Element } & \multicolumn{3}{|c|}{ Summer } & \multicolumn{3}{|c|}{ Winter } \\
\hline & Average & Min & Max & Average & Min & Max \\
\hline $\mathrm{Ag}$ & 0.42 & 0.2 & 0.9 & 0.31 & 0.1 & 0.5 \\
\hline $\mathrm{Al}$ & 3800 & 200 & 14000 & 1800 & 400 & 8500 \\
\hline As & 2 & 0.5 & 9 & 3 & 0.2 & 15 \\
\hline $\mathrm{Ba}$ & 4 & 2 & 8 & 13 & 3 & 57 \\
\hline $\mathrm{Br}$ & 14 & 3 & 51 & 5 & 0.4 & 18 \\
\hline $\mathrm{Ca}$ & 2400 & 300 & 5800 & 1800 & 300 & 2500 \\
\hline $\mathrm{Cd}$ & 0.9 & 0.2 & 4 & 0.9 & 0.2 & 5 \\
\hline $\mathrm{Ce}$ & 1 & 0.09 & 3 & 0.7 & 0.1 & 4 \\
\hline $\mathrm{Cl}$ & 1300 & 300 & 9300 & 1400 & 200 & 5400 \\
\hline Co & 0.4 & 0.05 & 2.1 & 0.3 & 0.04 & 2.4 \\
\hline $\mathrm{Cr}$ & 6 & 1 & 12 & 9 & 1 & 21 \\
\hline Cs & 0.2 & 0.01 & 1.9 & 0.3 & 0.01 & 1.6 \\
\hline $\mathrm{Eu}^{\mathrm{a}}$ & 0.15 & 0.02 & 0.22 & 0.11 & 0.02 & 0.24 \\
\hline $\mathrm{Fe}$ & 1850 & 600 & 4800 & 1500 & 350 & 4100 \\
\hline$H f^{a}$ & 91 & 21 & 320 & 75 & 11 & 250 \\
\hline $\mathrm{Hg}$ & 0.64 & 0.1 & 1.6 & 0.45 & 0.1 & 1.5 \\
\hline I & 6 & 2 & 12 & 4 & 3 & 9 \\
\hline K & 930 & 100 & 3400 & 490 & 50 & 2800 \\
\hline $\mathrm{La}^{\mathrm{a}}$ & 12 & 1 & 38 & 7 & 0.9 & 25 \\
\hline $\mathrm{Mg}$ & 1490 & 100 & 3500 & 950 & 100 & 1500 \\
\hline $\mathrm{Mn}$ & 52 & 12 & 98 & 37 & 10 & 85 \\
\hline Mo & 3.4 & 0.4 & 12 & 2.8 & 0.2 & 11 \\
\hline $\mathrm{Na}$ & 2500 & 300 & 9800 & 1530 & 200 & 5200 \\
\hline $\mathrm{Ni}$ & 5.5 & 1 & 19 & 4 & 1 & 15 \\
\hline $\mathrm{Pb}$ & 42 & 12 & 157 & 54 & 15 & 250 \\
\hline $\mathrm{Rb}$ & 5 & 1 & 18 & 6 & 1 & 24 \\
\hline $\mathrm{Sb}$ & 8 & 0.5 & 17 & 9 & 0.4 & 31 \\
\hline $\mathrm{SC}^{\mathrm{a}}$ & 45 & 14 & 120 & 51 & 12 & 135 \\
\hline $\mathrm{Se}$ & 0.7 & 0.1 & 1.3 & 0.6 & 0.1 & 1.6 \\
\hline $\mathrm{Ta}$ & 0.02 & 0.01 & 0.09 & 0.03 & 0.01 & 1.1 \\
\hline $\mathrm{Tb}$ & 0.048 & 0.009 & 0.32 & 0.035 & 0.005 & 0.42 \\
\hline$T^{a}$ & 200 & 22 & 510 & 180 & 19 & 460 \\
\hline $\mathrm{Ti}$ & 250 & 50 & 930 & 124 & 100 & 630 \\
\hline $\mathrm{Tl}$ & 1.2 & 0.3 & 6 & 1.7 & 0.5 & 9 \\
\hline U & 0.3 & 0.02 & 0.9 & 0.2 & 0.03 & 0.8 \\
\hline V & 15 & 1 & 34 & 21 & 5 & 49 \\
\hline $\mathrm{Zn}$ & 130 & 25 & 290 & 180 & 40 & 640 \\
\hline $\mathrm{Zr}$ & 45 & 5 & 75 & 39 & 7 & 61 \\
\hline
\end{tabular}

Table 5 Seasonal element concentrations (average, min and max levels expressed as $\mathrm{ng} \mathrm{m}^{-3}$ ) in $\mathrm{PM}_{10}$ determined by INAA and IPAA in atmospheric particulate sampled in downtown Rome

\begin{tabular}{|c|c|c|c|c|c|c|}
\hline \multirow[t]{2}{*}{ Element } & \multicolumn{3}{|c|}{ Summer } & \multicolumn{3}{|c|}{ Winter } \\
\hline & Average & Min & $\operatorname{Max}$ & Average & Min & Max \\
\hline $\mathrm{Ag}$ & 0.22 & 0.1 & 0.5 & 0.25 & 0.1 & 0.6 \\
\hline $\mathrm{Al}$ & 2900 & 500 & 5300 & 800 & 200 & 1600 \\
\hline As & 6 & 1 & 15 & 4 & 1 & 9 \\
\hline $\mathrm{Ba}$ & 60 & 30 & 120 & 30 & 5 & 70 \\
\hline $\mathrm{Br}$ & 40 & 20 & 70 & 70 & 10 & 140 \\
\hline $\mathrm{Ca}$ & 2200 & 800 & 4200 & 1200 & 300 & 2000 \\
\hline $\mathrm{Cd}$ & 0.4 & 0.3 & 0.9 & 0.75 & 0.3 & 2 \\
\hline $\mathrm{Ce}$ & 5.6 & 0.7 & 10 & 2 & 0.2 & 5 \\
\hline $\mathrm{Cl}$ & 1300 & 300 & 3900 & 1400 & 300 & 4700 \\
\hline Co & 0.7 & 0.4 & 1.2 & 0.5 & 0.1 & 0.9 \\
\hline $\mathrm{Cr}$ & 7 & 4 & 13 & 16 & 2 & 38 \\
\hline Cs & 1.2 & 0.6 & 2.2 & 0.6 & 0.2 & 1.3 \\
\hline $\mathrm{Eu}$ & 0.08 & 0.04 & 0.14 & 0.03 & 0.01 & 0.07 \\
\hline $\mathrm{Fe}$ & 2200 & 1000 & 3600 & 1100 & 400 & 2700 \\
\hline $\mathrm{Hf}$ & 0.36 & 0.15 & 0.62 & 0.13 & 0.01 & 0.30 \\
\hline $\mathrm{Hg}$ & 0.14 & 0.05 & 0.36 & 0.13 & 0.03 & 0.20 \\
\hline I & 6 & 3 & 8 & 6 & 3 & 10 \\
\hline K & 1120 & 50 & 1900 & 320 & 50 & 1000 \\
\hline La & 5 & 2 & 9 & 2 & 0.3 & 4 \\
\hline $\mathrm{Mg}$ & 1090 & 50 & 2700 & 560 & 200 & 1200 \\
\hline $\mathrm{Mn}$ & 40 & 15 & 60 & 35 & 10 & 90 \\
\hline Mo & 0.5 & 0.2 & 0.6 & 2 & 0.3 & 7 \\
\hline $\mathrm{Na}$ & 1500 & 300 & 7000 & 730 & 200 & 3500 \\
\hline $\mathrm{Ni}$ & 1.7 & 1 & 5 & 8 & 3 & 13 \\
\hline $\mathrm{Pb}$ & 120 & 80 & 200 & 270 & 80 & 840 \\
\hline $\mathrm{Rb}$ & 17 & 10 & 30 & 7 & 2 & 15 \\
\hline $\mathrm{Sb}$ & 2 & 0.7 & 4 & 2 & 0.7 & 7 \\
\hline SC & 0.3 & 0.1 & 0.5 & 0.1 & 0.03 & 0.2 \\
\hline $\mathrm{Se}$ & 0.7 & 0.2 & 1.1 & 0.5 & 0.2 & 1.3 \\
\hline $\mathrm{Ta}$ & 0.03 & 0.01 & 0.05 & 0.01 & 0.005 & 0.02 \\
\hline $\mathrm{Tb}$ & 0.055 & 0.1 & 0.10 & 0.024 & 0.01 & 0.05 \\
\hline Th & 3 & 1 & 5 & 0.9 & 0.3 & 2.5 \\
\hline $\mathrm{Ti}$ & 540 & 200 & 1050 & 265 & 200 & 500 \\
\hline $\mathrm{Tl}$ & 1 & 0.5 & 2 & 1.4 & 0.5 & 4 \\
\hline U & 0.4 & 0.1 & 0.7 & 0.2 & 0.06 & 0.4 \\
\hline V & 8 & 1 & 15 & 14 & 8 & 23 \\
\hline $\mathrm{Zn}$ & 110 & 50 & 260 & 190 & 50 & 520 \\
\hline $\mathrm{Zr}$ & 50 & 10 & 90 & 20 & 5 & 50 \\
\hline
\end{tabular}


Table 6 Grouping of elements in $\mathrm{PM}_{10}$ according to the ratio of summer to winter seasonal average

\begin{tabular}{lll}
\hline Ratio $>\mathbf{2}$ & Ratio $\mathbf{1}$ & Ratio $<\mathbf{1}$ \\
\hline Outskirt & & \\
$\mathrm{Al}, \mathrm{Ba}, \mathrm{Ca}, \mathrm{Ce}, \mathrm{Cs}, \mathrm{Eu}, \mathrm{Fe}$, & $\mathrm{Ag}, \mathrm{As}, \mathrm{Br}, \mathrm{Cl}, \mathrm{Co}, \mathrm{Hg}, \mathrm{I}$, & $\mathrm{Cd}, \mathrm{Cr}, \mathrm{Mo}, \mathrm{Ni}$, \\
$\mathrm{Hf}, \mathrm{K}, \mathrm{La}, \mathrm{Mg}, \mathrm{Na}, \mathrm{Rb}, \mathrm{Sc}$, & $\mathrm{Mn}, \mathrm{Sb}, \mathrm{Se}, \mathrm{Tl}$ & $\mathrm{Pb}, \mathrm{V}, \mathrm{Zn}$ \\
$\mathrm{Ta}, \mathrm{Tb}, \mathrm{Th}, \mathrm{Ti}, \mathrm{U}, \mathrm{Zr}$ & & \\
Downtown & & \\
\hline $\mathrm{Al}, \mathrm{Br}, \mathrm{K}, \mathrm{Na}, \mathrm{Ti}, \mathrm{U}$ & $\mathrm{Ag}, \mathrm{Ca}, \mathrm{Cd}, \mathrm{Ce}, \mathrm{Co}, \mathrm{Eu}$, & $\mathrm{As}, \mathrm{Ba}, \mathrm{Cl}, \mathrm{Cr}, \mathrm{Cs}$, \\
& $\mathrm{Fe}, \mathrm{Hf}, \mathrm{La}, \mathrm{Mg}, \mathrm{Mn}, \mathrm{Mo}$, & $\mathrm{I}, \mathrm{Pb}, \mathrm{Rb}, \mathrm{Sb}, \mathrm{Sc}$, \\
& $\mathrm{Ni}, \mathrm{Se}, \mathrm{Tb}, \mathrm{Th}, \mathrm{Zr}$ & $\mathrm{Ta}, \mathrm{Tl}, \mathrm{V}, \mathrm{Zn}$ \\
\hline
\end{tabular}

found in this study for $\mathrm{Al}, \mathrm{Cs}, \mathrm{Na}, \mathrm{Rb}, \mathrm{Th}, \mathrm{Ti}, \mathrm{U}$ and rare earths are to be related to the element content of the volcanic rocks which are very widespread in Latium [30,31].

\section{The enrichment factor (EF) application}

In order to investigate a retrospective study of elements in $\mathrm{PM}_{10}$ and their evolution in relationship with the natural or anthropogenic origins, Table 7 reports the levels of selected elements collected in the last 4 decades: the data obtained show a decrease ranging between 24\% (Co) and 91\% (La), except for $\mathrm{Hg}$, Sb and Se. Basically, this may be attributed to the technological growth during the entire period and to the adoption of anti-pollution system in domestic heating and in industrial plants. Mercury decreases slowly (during the four decades the values are almost similar ranging between 0.09 and 0.13) whereas Se increases except during the period 1989-92 (probably due to the sample site choice), and $\mathrm{Sb}$ is 4-times higher than the seventies. For a better knowledge of this evolution and, expecially, of the element origin, we have calculated the enrichment factors

Table 7 Levels $\left(\mathrm{ng} \mathrm{m}^{-3}\right)$ of selected elements in $\mathrm{PM}_{10}$ investigated along four decades in downtown Rome

\begin{tabular}{lccc}
\hline & \multicolumn{3}{c}{$\mathbf{P M}_{\mathbf{1 0}}$} \\
\cline { 2 - 4 } & $\mathbf{1 9 6 5 - 7 8}$ & $\mathbf{1 9 8 9 - 9 2}$ & $\mathbf{2 0 0 0 - 0 5}$ \\
\hline $\mathrm{As}$ & 4.00 & & 1.35 \\
$\mathrm{Br}$ & 70 & 50 & 22 \\
$\mathrm{Cd}$ & 0.751 & & 0.520 \\
$\mathrm{Co}$ & 0.498 & 0.523 & 0.379 \\
$\mathrm{Cr}$ & 16 & 2.3 & 7.28 \\
$\mathrm{Hg}$ & 0.131 & 0.092 & 1.07 \\
$\mathrm{La}$ & 2.04 & 0.803 & 0.188 \\
$\mathrm{Ni}$ & 1.72 & 4.54 \\
$\mathrm{~Pb}$ & 8.01 & 172 & 92 \\
$\mathrm{Sb}$ & 270 & 2.13 & 9.22 \\
$\mathrm{Se}$ & 1.99 & 0.091 & 0.692 \\
$\mathrm{Th}$ & 0.533 & 0.723 & 0.229 \\
$\mathrm{~V}$ & 0.911 & 4.82 & 4.02 \\
$\mathrm{Zn}$ & 14 & 28 & 80 \\
\hline
\end{tabular}

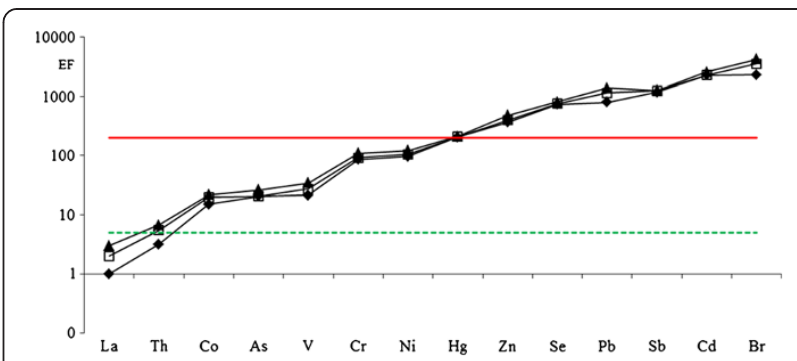

Figure $1 \mathrm{EF}$ trend comparison of selected trace elements in PM10 fraction calculated using La as normalizing element. period 1965-78; 口: period 1989-92; period 2000-05

(EFs) with respect to the element abundance in the upper continental crust. Elements with EF values much higher than 1 can be considered of non-crustal origin and may be attributed to long-transport phenomena from other natural and/or anthropogenic sources. The EFs have been calculated in according to the equation reported in refs. [7,32] and La as normalizing element [21]. Figure 1 shows the EF trend for selected elements in $\mathrm{PM}_{10}$ during four decedes. As can be noted, all the elements may be attributed to long-range transport phenomena from other natural and/ or anthropogenic sources: this behavior is common to all the period studied even if a very light decreasing trend can be evidenced from 1970 to 2005.

In Figure 1, showing the EFs of some elements, three groups can be identified: La and Th ranging between 1 and 5; Co, As, V, Cr and $\mathrm{Ni}$ between 1 and 100; $\mathrm{Hg}, \mathrm{Zn}$, $\mathrm{Se}, \mathrm{Pb}, \mathrm{Sb}, \mathrm{Cd}$ and Br ranging between 200 and 2500.

Basically, some particular considerations can be extrapolated: the high EF values found for $\mathrm{Br}$ (and $\mathrm{Pb}$ as well) by both the elaborations could be attributed to the use of leaded gasoline gasoline (cars with leaded gasoline are still present at the end of nineties'); the sources of $\mathrm{As}, \mathrm{Pb}, \mathrm{Sb}$ and $\mathrm{Zn}$ would be looked for among the various anthropogenic activities in the Rome area and particularly $\mathrm{Sb}$ and $\mathrm{Zn}$ could be of traffic origin being essential components of anti-friction alloys and car tires.

Finally, a same approach has been performed to elements investigated in the $\mathrm{PM}_{2.5}$ fraction, even if no historical data

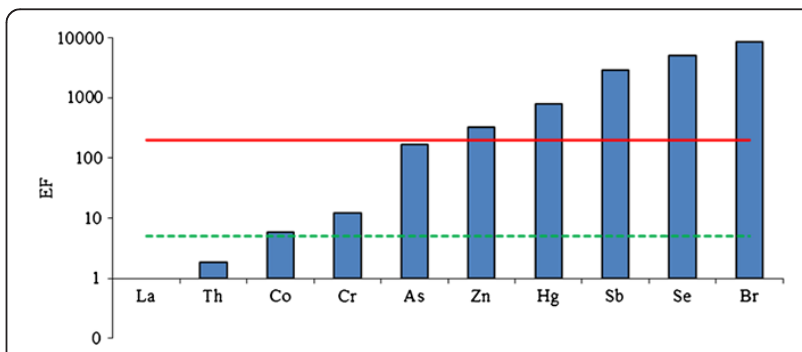

Figure $2 \mathrm{EFs}$ of selected elements in $\mathrm{PM}_{2.5}$ fraction calculated using La as normalizing element. 
Table 8 Nuclear data and LOD of elements by INAA and IPAA (m: minutes; h: hours; d: days; y: years)

\begin{tabular}{|c|c|c|c|c|c|}
\hline \multirow{2}{*}{$\frac{\text { Element }}{I N A A}$} & \multirow[t]{2}{*}{ Product nuclide } & \multicolumn{2}{|c|}{ Half life } & \multirow[t]{2}{*}{ Y-Ray used (keV) } & \multirow[t]{2}{*}{$\operatorname{LOD}(\mathrm{g})$} \\
\hline & & & & & \\
\hline $\mathrm{Ag}$ & ${ }^{110 \mathrm{~m}} \mathrm{Ag}$ & 253.0 & d & 657.8 & $1 \times 10^{-10}$ \\
\hline $\mathrm{Al}$ & ${ }^{28} \mathrm{Al}$ & 2.3 & $\mathrm{~m}$ & 1778.9 & $3 \times 10^{-8}$ \\
\hline As & ${ }^{76}$ As & 26.3 & $\mathrm{~h}$ & 559.2 & $1 \times 10^{-12}$ \\
\hline $\mathrm{Au}$ & ${ }^{198} \mathrm{Au}$ & 2.70 & d & 411.8 & $6 \times 10^{-14}$ \\
\hline $\mathrm{Ba}$ & ${ }^{131} \mathrm{Ba}$ & 11.5 & d & 496.3 & $2 \times 10^{-10}$ \\
\hline $\mathrm{Br}$ & ${ }^{82} \mathrm{Br}$ & 1.47 & $d$ & 776.5 & $2 \times 10^{-12}$ \\
\hline $\mathrm{Ca}$ & ${ }^{49} \mathrm{Ca}$ & 8.8 & $\mathrm{~m}$ & 3083.0 & $2 \times 10^{-7}$ \\
\hline $\mathrm{Cd}$ & $115 \mathrm{~m} / \mathrm{n}$ & 53.0 & $\mathrm{~h}$ & 336.6 & $3 \times 10^{-11}$ \\
\hline $\mathrm{Ce}$ & ${ }^{141} \mathrm{Ce}$ & 32.38 & $d$ & 145.4 & $8 \times 10^{-10}$ \\
\hline $\mathrm{Cl}$ & ${ }^{38} \mathrm{Cl}$ & 37.3 & & 1642.0 & $2 \times 10^{-9}$ \\
\hline Co & ${ }^{60} \mathrm{Co}$ & 5.272 & $y$ & 1332.5 & $6 \times 10^{-11}$ \\
\hline $\mathrm{Cr}$ & ${ }^{51} \mathrm{Cr}$ & 27.7 & $d$ & 320.0 & $1 \times 10^{-10}$ \\
\hline Cs & ${ }^{134} \mathrm{Cs}$ & 2.062 & y & 795.7 & $1 \times 10^{-11}$ \\
\hline $\mathrm{Eu}$ & ${ }^{152} \mathrm{Eu}$ & 12.7 & y & 1408.0 & $2 \times 10^{-12}$ \\
\hline $\mathrm{Fe}$ & ${ }^{59} \mathrm{Fe}$ & 45.1 & $d$ & 1099.2 & $2 \times 10^{-8}$ \\
\hline $\mathrm{Hf}$ & ${ }^{181} \mathrm{Hf}$ & 42.4 & $d$ & 482.2 & $2 \times 10^{-11}$ \\
\hline $\mathrm{Hg}$ & ${ }^{203} \mathrm{Hg}$ & 46.9 & $d$ & 279.0 & $4 \times 10^{-11}$ \\
\hline 1 & 128 & 25.0 & $\mathrm{~m}$ & 442.7 & $8 \times 10^{-11}$ \\
\hline K & ${ }^{42} \mathrm{~K}$ & 12.52 & $\mathrm{~h}$ & 1524.7 & $2 \times 10^{-10}$ \\
\hline La & ${ }^{140} \mathrm{La}$ & 40.27 & $\mathrm{~h}$ & 1596.2 & $1 \times 10^{-12}$ \\
\hline $\mathrm{Mg}$ & ${ }^{27} \mathrm{Mg}$ & 9.5 & $\mathrm{~m}$ & 1014.1 & $2 \times 10^{-8}$ \\
\hline $\mathrm{Mn}$ & ${ }^{56} \mathrm{Mn}$ & 2.58 & $\mathrm{~h}$ & 1810.7 & $8 \times 10^{-13}$ \\
\hline Mo & ${ }^{99} \mathrm{Mo}$ & 2.75 & $d$ & 141.0 & $3 \times 10^{-11}$ \\
\hline $\mathrm{Na}$ & ${ }^{24} \mathrm{Na}$ & 15.0 & $\mathrm{~h}$ & 1368.4 & $4 \times 10^{-12}$ \\
\hline $\mathrm{Nd}$ & ${ }^{147} \mathrm{Nd}$ & 11.1 & $d$ & 531.0 & $1 \times 10^{-11}$ \\
\hline $\mathrm{Ni}$ & ${ }^{58} \mathrm{Co}$ & 70.78 & $d$ & 810.7 & $6 \times 10^{-9}$ \\
\hline $\mathrm{Rb}$ & ${ }^{86} \mathrm{Rb}$ & 18.66 & $d$ & 1076.7 & $8 \times 10^{-10}$ \\
\hline $\mathrm{Sb}$ & ${ }^{122} \mathrm{Sb}$ & 2.70 & d & 564.0 & $1 \times 10^{-12}$ \\
\hline $\mathrm{SC}$ & ${ }^{46} \mathrm{SC}$ & 83.85 & $d$ & 889.2 & $2 \times 10^{-12}$ \\
\hline $\mathrm{Se}$ & ${ }^{75} \mathrm{Se}$ & 120.4 & $d$ & 264.6 & $1 \times 10^{-10}$ \\
\hline $\mathrm{Sm}$ & ${ }^{153} \mathrm{Sm}$ & 1.948 & $d$ & 103.1 & $6 \times 10^{-13}$ \\
\hline $\mathrm{Ta}$ & ${ }^{182} \mathrm{Ta}$ & 115 & $d$ & 1221.6 & $1 \times 10^{-11}$ \\
\hline $\mathrm{Tb}$ & ${ }^{160} \mathrm{~Tb}$ & 72.1 & $d$ & 879.4 & $2 \times 10^{-12}$ \\
\hline Th & ${ }^{233} \mathrm{~Pa}$ & 27.4 & $d$ & 311.8 & $1 \times 10^{-11}$ \\
\hline $\mathrm{Ti}$ & ${ }^{51} \mathrm{Ti}$ & 5.8 & $\mathrm{~m}$ & 320.0 & $1 \times 10^{-8}$ \\
\hline U & ${ }^{239} \mathrm{~Np}$ & 2.35 & d & 228.2 & $5 \times 10^{-12}$ \\
\hline V & ${ }^{52} \mathrm{~V}$ & 3.76 & $\mathrm{~m}$ & 1434.4 & $9 \times 10^{-10}$ \\
\hline W & ${ }^{187} \mathrm{~W}$ & 24.0 & $\mathrm{~h}$ & 685.7 & $1 \times 10^{-12}$ \\
\hline $\mathrm{Yb}$ & ${ }^{175} \mathrm{Yb}$ & 4.21 & $d$ & 396.1 & $1 \times 10^{-12}$ \\
\hline $\mathrm{Zn}$ & ${ }^{65} \mathrm{Zn}$ & 243.8 & $d$ & 1115.5 & $1 \times 10^{-10}$ \\
\hline \multicolumn{6}{|l|}{ IPAA } \\
\hline As & ${ }^{76} \mathrm{As}$ & 1.097 & $d$ & 559.1 & $10^{-7}$ \\
\hline
\end{tabular}

Table 8 Nuclear data and LOD of elements by INAA and IPAA (m: minutes; h: hours; d: days; y: years) (Continued)

\begin{tabular}{cccccc}
\hline $\mathrm{Ca}$ & ${ }^{47} \mathrm{Ca}$ & 4.536 & $\mathrm{~d}$ & 1297.1 & $10^{-7}$ \\
$\mathrm{Ce}$ & ${ }^{141} \mathrm{Ce}$ & 32.5 & $\mathrm{~d}$ & 145.4 & $10^{-7}$ \\
$\mathrm{Cr}$ & ${ }^{51} \mathrm{Cr}$ & 27.7 & $\mathrm{~d}$ & 320.0 & $10^{-8}$ \\
$\mathrm{Cs}$ & ${ }^{134} \mathrm{Cs}$ & 2.062 & $\mathrm{y}$ & 795.9 & $10^{-8}$ \\
$\mathrm{Mn}$ & ${ }^{54} \mathrm{Mn}$ & 312.2 & $\mathrm{~d}$ & 834.8 & $10^{-6}$ \\
$\mathrm{Nb}$ & ${ }^{92 \mathrm{~m}} \mathrm{Nb}$ & 10.15 & $\mathrm{~d}$ & 934.5 & $10^{-8}$ \\
$\mathrm{~Pb}$ & ${ }^{204} \mathrm{~Pb}$ & 52.1 & $\mathrm{~h}$ & 279.0 & $10^{-7}$ \\
$\mathrm{Sr}$ & ${ }^{85} \mathrm{Sr}$ & 64.84 & $\mathrm{~d}$ & 514.0 & $10^{-6}$ \\
$\mathrm{Ti}$ & ${ }^{47} \mathrm{SC}$ & 3.341 & $\mathrm{~d}$ & 159.4 & $10^{-8}$ \\
$\mathrm{Tl}$ & ${ }^{203} \mathrm{Tl}$ & 12.0 & $\mathrm{~d}$ & 440.0 & $10^{-7}$ \\
$\mathrm{Y}$ & ${ }^{88} \mathrm{Y}$ & 106.61 & $\mathrm{~d}$ & 1836.1 & $10^{-7}$ \\
$\mathrm{Zr}$ & ${ }^{90} \mathrm{Zr}$ & 79.4 & $\mathrm{~h}$ & 909.0 & $10^{-8}$ \\
\hline
\end{tabular}

LODs calculated according to ref. [36] for matrix free elements, i.e. without disturbing activities from a sample matrix.

series are available. Figure 2 reports the results obtained on the $\mathrm{PM}_{2.5}$ fraction: $\mathrm{Co}, \mathrm{Cr}, \mathrm{As}, \mathrm{Zn}, \mathrm{Hg}, \mathrm{Sb}$, Se and Br show EF values ranging between 5 and 8500 , respectively.

It should be noted that the EFs in $\mathrm{PM}_{2.5}$ fraction is more elevated that in $\mathrm{PM}_{10}$ fraction, expecially for $\mathrm{Br}$, $\mathrm{Se}, \mathrm{Sb}$ and $\mathrm{Hg}$ : this could be due to the different granulometric size and the different ability to penetrate of such elements. This occurrence can be an index of the different bioavailability of an element series present in $\mathrm{PM}_{2.5}$ fraction compared to $\mathrm{PM}_{10}$ fraction. As reported above, the higher $\mathrm{EF}$ value found for $\mathrm{Br}$ and attributed to the use of leaded, is more evident in this fraction.

\section{Conclusions}

The experimentation has been addressed for getting the maximum analytical informative ability from the single sample determinations. The INAA and IPAA techniques allow to reach such elevated sensibility/accuracy levels to furnish discreet values for elements present at very low concentrations (trace and ultra-trace levels). In particular, IPAA is a unusual technique but its coupling with INAA, another nuclear methodology, can be useful for solving a lot of analytical problems.

The element concentrations determined in this study do not seem to show significant level of attention from a toxicological point of view, stressing preliminary results obtained in previous studies $[7,9]$. On the other hand, the element behavior trend during these last 40 years in downtown Rome is lightly decreasing although their main source is the anthropogenic activities.

\section{Experimental}

\section{Sampling}

The sample collection has been performed in a large period of time, almost 40 years: this means that the operation sampling has been carried out by means of different 
samplers. During the seventies the sampling occurred with no cut-off whereas since nineties the sampling heads have been introduced allowing to separate different granulometric fraction (firstly $\mathrm{PM}_{10}$ and after $\mathrm{PM}_{2.5}$ ). In particular, the latter campaigns were performed by a dichotomous sampler (mod. SA 241, Graseby,Andersen) operating at $16.7 \mathrm{~L} \mathrm{~min}^{-1}$. This sampler has a PM10 size selective inlet and separates the aerosol into fine (aerodynamic diameter, $D_{a},<2.5 \mu \mathrm{m}$ ) and coarse $\left(2.5 \mu \mathrm{m}<\mathrm{D}_{\mathrm{a}}<10 \mu \mathrm{m}\right)$ fractions. Particulate matter was collected on polymethylpentane ringed, $2.0 \mu \mathrm{m}$ pore size, $37 \mu \mathrm{m}$, Teflon membranes (Gelman, type R2PJ). This sampler has been designed as reference by USA-EPA. The $\mathrm{PM}_{2.5}$ samples were stored in box at controlled conditions (atmosphere and temperature).

About 300 air samples have been collected in downtown Rome (via Urbana, an area characterized by high presence of anthropogenic activities) and Roman outskirt (Anguillara area, a rural site); all the sampling were performed at ground level. The sampling was 24-hr long for each filter. All the storage and handling sample treatment were carried out at the ENEA and ISPESL laboratories.

\section{INAA and IPAA analyses}

Among the different analytical methodologies available for element determination we used nuclear approach for its important analytical properties $[7,9,20,21,33]$. In fact, the various analytical techniques (spectroscopy, electrochemistry, chromatography, bioanalytical methods) [34,35] do not permit to have the maximum information because of their limitations. INAA is well known as reference analytical technique because all the experimental steps are totally traceable and there is absence of physical-chemical sample manipulation reducing the positive and/or negative artifacts formation [7,9,20,21]. Furthermore, because of its high sensitivity, multi-elemental character allowing the determination of about 40 elements with a good Limit of

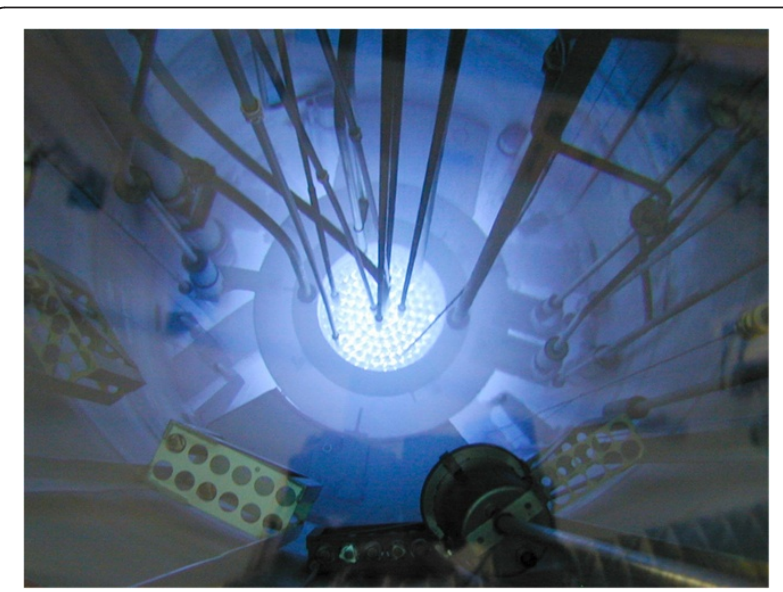

Figure 3 Triga nuclear reactor (1 MW) core with Cherenkov effect.

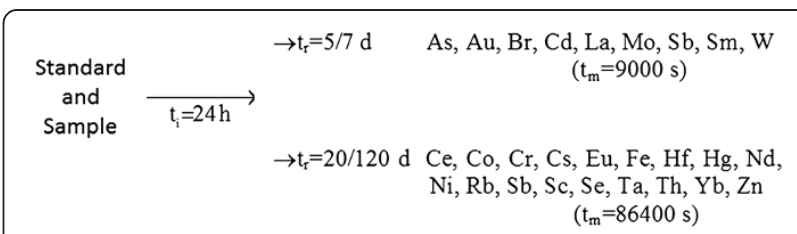

Figure 4 Scheme for INAA analysis of standards and samples ( $t_{\mathrm{i}}$ : irradiation time; $t_{\mathrm{r}}$ : cooling time; $t_{\mathrm{m}}$ : measurement time).

Detection (LOD) [36] (Table 8) and accuracy, the INAA has surpassed other instrumental methods for trace/ultratrace metal and rare hearths analysis: a comparative study [37-41], however, has pointed out that INAA is blank free and expecially suitable for the analysis of reference materials [41]. Further, we used IPAA as a complementary technique for determining elements: in particular, $\mathrm{Pb}, \mathrm{Tl}$ and $\mathrm{Zr}$ which are difficult to determine by INAA, are important from toxicological and environmental point of view.

Table 8 shows the nuclear data (as product nuclide, half-life and energy peak emission) and LOD (expressed as $\mathrm{ng} \mathrm{m}^{-3}$ ) of each element investigated in this study by means of INAA and IPAA. It should be noted the very low LODs reached by nuclear techniques in relation with other analytical methodologies [20,22].

INAA - Samples, blank and standards, put in nucleargrade polyethene cylinders (Kartell), were irradiated at a neutron flux of $2.6 \times 10^{12} \mathrm{n} \times \mathrm{cm}^{-2} \times \mathrm{s}^{-1}$ for $32.55 \mathrm{~h}$ in rotatory rack "Lazy Susan" of the nuclear reactor Triga Mark II of the ENEA-Casaccia Laboratories (Figure 3) [42].

For the analysis primary and secondary standards were used. Primary standards (Carlo Erba, Milano, Italy) were As, Cd, Co, Cr, Cs, Fe, Hg, La, Ni, Sb, Se, Sm and Zn whereas as secondary standards United States Geochemical Survey (U.S.G.S.) nn. 1, 4, 6 and the Coal Fly Ash (NIST) n. 1633a were used.

After irradiation, $\gamma$-ray spectrometry measurements of different duration (Figure 4) were carried out using a HPGe detector (FWHM $1.68 \mathrm{keV}$ at $1332 \mathrm{keV}$ ) connected to a multichannel analyzer equipped with software packages for a $\gamma$-spectra analysis.

A first measurement series was performed $5 / 7$ days after the end of irradiation with measurement times of 3000 and $9000 \mathrm{~s}$ for sample for determining $\mathrm{As}, \mathrm{Au}, \mathrm{Br}$, Cd, La, Mo, Sb, Sm, W [7,13,40]. The second series was performed 20/120 days after the end of irradiation with measurement times of 24-100 h for sample for determining $\mathrm{Ce}, \mathrm{Co}, \mathrm{Cr}, \mathrm{Cs}, \mathrm{Eu}, \mathrm{Fe}, \mathrm{Hf}, \mathrm{Hg}, \mathrm{Nd}, \mathrm{Ni}, \mathrm{Rb}$, $\mathrm{Sb}, \mathrm{Sc}, \mathrm{Se}, \mathrm{Ta}, \mathrm{Th}, \mathrm{Yb}, \mathrm{Zn}[7,25,40]$.

IPAA - Samples, blank and standards (NIST SRM 1571) were irradiated in the photon beam of the INFN Frascati National Laboratory Linear Accelerator (LINAC) at an average beam current of $40 \mu \mathrm{A}$, maximum electron energy of $300 \mathrm{MeV}$ and a W converter of $0.3 \mathrm{~mm}$ thickness. 
Two series of measurements were carried out: after 36/70 hours As, $\mathrm{Ca}, \mathrm{Pb}, \mathrm{Ti}$ and $\mathrm{Zr}$ were measured for 2 hours whereas after 20 days from irradiation $\mathrm{Ce}, \mathrm{Cr}$, $\mathrm{Cs}, \mathrm{Mn}, \mathrm{Nb}, \mathrm{Sr}, \mathrm{Tl}$ and $\mathrm{Y}$ were counted for 4 hours.

\section{Competing interests}

The authors declare that they have no competing interests.

\section{Authors' contributions}

PA, MVR and GC coordinated the study. PA and AR set up the analytical procedure using INAA. MM processed data and provided the comparison with other literature. PA and AR edited the text and prepared the final draft of the paper. GC and MVR approved the final version. All the authors have read and approved the final manuscript.

\section{Acknowledgements}

This work was supported by INAIL under grants P20L09 and P20L01.

\section{Author details}

'DIPIA, INAIL settore Ricerca, Certificazione e Verifica, Via IV Novembre 144, Rome 00187, Italy. ${ }^{2}$ UTFISS CATNUC, ENEA, Via Anguillarese 301, Rome 00123, Italy. ${ }^{3}$ Department of Environment, Food and Agriculture, University of Molise, Via De Sanctis, Campobasso 86100, Italy.

Received: 4 April 2013 Accepted: 24 October 2013

Published: 6 November 2013

\section{References}

1. Dockery DW, Speizer FE, Stram DO, Ware JH, Spengler JD, Ferris BG Jr: Effects of inhalable particles on respiratory health of children. Am Rev Respir Dis 1989, 139(3):587-594

2. Dockey DW, Pope CA: Acute respiratory effects of particulate air pollution. Annu Rev Public Health 1994, 15:107-132.

3. Harrison RM, Yin J: Particulate matter in the atmosphere: which particle properties are important for its effects on health? Sci Total Environ 2000, 249(1-3):85-101.

4. Cao L, Tian W, Ni B, Zhang Y, Wang P: Preliminary study of airborne particulate matter in a Beijing sampling station by instrumental neutron activation analysis. Atmos Environ 2002, 36(12):1951-1956.

5. Avino P, Brocco D, Cecinato A, Lepore L, Balducci C: Carbonaceous components in atmospheric aerosol: measurements, procedures and characterization. Ann Chim (Rome) 2002, 92(4):333-341.

6. Avino P, Brocco D: Carbonaceous aerosol in the breathable particulate matter (PM10) in urban area. Ann Chim (Rome) 2004, 94(9-10):647-653.

7. Avino P, Capannesi G, Rosada A: Characterization and distribution of mineral content in fine and coarse airborne particle fractions by neutron activation analysis. Toxicol Environ Chem 2006, 88(4):633-647.

8. Avino $\mathrm{P}$, Manigrasso $\mathrm{M}$ : Vertical distribution of carbonaceous material in urban atmosphere. Fresenius Environ Bull 2006, 15(8b):866-877.

9. Avino P, Capannesi G, Rosada A: Heavy metal determination in atmospheric particulate matter by Instrumental Neutron Activation Analysis. Microchem J 2008, 88(2):97-106.

10. Manigrasso M, Febo A, Guglielmi F, Ciambottini V, Avino P: Relevance of aerosol size spectrum analysis as support to qualitative source apportionment studies. Environ Pollut 2012, 170:43-51.

11. Manigrasso $M$, Avino P: Fast evolution of urban ultrafine particles: implications for deposition doses in the human respiratory system. Atmos Environ 2012, 51:116-123.

12. Agency IAE: Analytical Applications of Nuclear Techniques. Wien: IAEA; 2004. ISBN 9201147031.

13. Avino P, Santoro E, Sarto F, Violante V, Rosada A: Neutron activation analysis for investigating purity grade of copper, nickel and palladium thin films used in cold fusion experiments. J Radioanal Nucl Chem 2011, 290(2):427-436

14. Capannesi G, Rosada A, Manigrasso M, Avino P: Rare earth elements, thorium and uranium in ores of the North- Latium (Italy). J Radioanal Nucl Chem 2012, 291(1):163-168.

15. Segebade C, Weise HP, Lutz GJ: Photon Activation Analysis. Berlin: Walter de Gruyter InC; 1988. ISBN ISBN: 0899253059.
16. Oprea C, Maslov OD, Gustova MV, Oprea IA, Mihul A, Belov AG, Szalanski PJ, Buzguta V: Photoneutron activation analysis applied for environmental researches. Rom Rep Phys 2011, 63(2):348-356

17. Mizera J, Randa Z: Instrumental neutron and photon activation analyses of selected geochemical reference materials. J Radioanal Nucl Chem 2010, 284(1):157-163.

18. Campanella L, Crescentini G, Avino P, Moauro A: Determination of macrominerals and trace elements in the alga Spirulina platensis. Analusis 1998, 26:210-214.

19. Avino P, Carconi PL, Lepore L, Moauro A: Nutritional and environmental properties of algal products used in healthy diet by INAA and ICP-AES. J Radioanal Nucl Chem 2000, 244(1):247-252.

20. Capannesi G, Diaco L, Rosada A, Avino P: Investigation of trace and ultra-trace elements of nutritional and toxicological significance in Italian potable waters by INAA. J Radioanal Nucl Chem 2008, 278(2):353-357.

21. Capannesi G, Rosada A, Avino P: Elemental characterization of impurities at trace and ultra-trace levels in metallurgical lead samples by INAA. Microchem J 2009, 93(2):188-194.

22. Avino P, Capannesi G, Diaco L, Rosada A: Multivariate analysis applied to trace and ultra-trace elements in Italian potable waters determined by INAA. Curr Anal Chem 2010, 6(1):26-36.

23. Capannesi G, Rosada A, Avino P: Radiochemical separation and antiCompton analysis of $\mathrm{Ni}, \mathrm{Sn}, \mathrm{Te}$ and $\mathrm{Zn}$ in lead standard reference materials at ultra-trace levels. Curr Anal Chem 2010, 6(3):217-222.

24. Buonanno G, Stabile L, Avino P, Vanoli R: Dimensional and chemical characterization of particles at a downwind receptor site of a waste-toenergy plant. Waste Manag 2010, 30(7):1325-1333.

25. Avino P, Capannesi G, Rosada A: Ultra-trace nutritional and toxicological elements in Rome and Florence drinking waters determined by Instrumental Neutron Activation Analysis. Microchem J 2011, 97(2):144-153.

26. Avino P, Capannesi G, Manigrasso M, Sabbioni E, Rosada A: Element assessment in whole blood, serum and urine of three Italian healthy sub-populations by INAA. Microchem J 2011, 99(2):548-555.

27. Avino P, Capannesi G, Renzi L, Rosada A: Instrumental neutron activation analysis and statistical approach for determining baseline values of essential and toxic elements in hairs of high school students. Ecotoxicol Environ Saf 2013, 92:206-214

28. Randa Z, Frána J, Mizera J, Kucera J, Novák JK, Ulrych J, Belov AG, Maslov OD: Instrumental neutron and photon activation analysis in the geochemical study of phonolitic and trachytic rocks. Geostand Geoanal Res 2007, 31(3):275-283.

29. Avino P, Capannesi G, Lopez F, Rosada A: Determination of interesting toxicological elements in $\mathrm{PM}_{2.5}$ by neutron and photon activation analysis. Sci World J 2013, article ID 458793. doi: 10.1155/2013/458793.

30. Locardi E, Sircana S: Distribuzione dell'uranio e del torio nelle vulcaniti quaternarie alcaline del Lazio settentrionale. Rend Soc Mineralog Ital 1967, 23:163-224.

31. Locardi E, Mittempergher M: Relationship between some trace elements and magmatic processes. Inter J Earth Sci (Geologische Rundschau) 1967, 57(1):313-334

32. Bergamaschi L, Rizzio E, Valcuvia MG, Verza G, Profumo A, Gallorini M: Determination of trace elements and evaluation of their enrichment factors in Himalayan lichens. Environ Pollut 2002, 120(1):137-144.

33. Campanella L, Crescentini G, Avino P: Chemical composition and nutritional evaluation of some natural and commercial food products based on Spirulina. Analusis 1999, 27(6):533-540.

34. Bruni F, Manzari C, Filice M, Polosa PL, Colella M, Carmone C, Hambardjieva E, Garcia-Diaz M, Cantatore P, Roberti M: D-MTERF5 is a novel factor modulating transcription in Drosophila mitochondria. Mitochondrion 2012, 12(5):492-499.

35. Cardone A, Lopez F, Affortunato F, Busco G, Hofer AM, Mallamaci R, Martinelli C, Colella M, Farinola GM: An aryleneethynylene fluorophore for cell membrane staining. BBA-Biomembranes 2012, 1818(11):2808-2817.

36. Currie LA: Limits for qualitative detection and quantitative determination. Application to radiochemistry. Anal Chem 1968, 40(3):586-593.

37. Farinha MM, Freitas MC, Almeida SM, Reis MA: Some improvements in air particulate matter analysis by INAA. Radiat Phys Chem 2001, 61(3):659-661.

38. Carmo Freitas M, Almeida SM, Reis MA, Oliveira OR: Monitoring trace elements by nuclear techniques in PM10 and PM2.5. Nucl Instrum Methods Phys Res A 2003, 505(1-2):430-434. 
39. Almeida SM, Reis MA, Freitas MC, Pio CA: Quality assurance in elemental analysis of airborne particles. Nucl Instrum Methods Phys Res, Sect B 2003, 207(4):434-446.

40. Djingova R, Arpadjan S, Kuleff I: INAA and flame AAS of various vegetable reference materials. Fresenius J Anal Chem 1991, 339(3):181-186.

41. Djingova R, Kuleff I: Instrumental techniques for trace analysis. In Trace Elements Their Distribution and Effects in the Environment. Edited by Markert B, Friese $\mathrm{K}$. Amsterdam, The Netherlands: Elsevier; 2000:137-185. ISBN ISBN-13: 9780444505323.

42. Di Palo L, Focaccia G, Lo Prato E, Marsili F, Paletti A, Perni M, Prosperi D, Sciuti S, Verri A: II reattore RC-1 ad 1 MW del Centro Studi Nucleari della Casaccia. Caratteristiche generali e programmi di ricerca. Ener Nuc 1967, 14:659-664.

doi:10.1186/1752-153X-7-173

Cite this article as: Avino et al: Deep investigation on inorganic fraction of atmospheric PM in Mediterranean area by neutron and photon activation analysis. Chemistry Central Journal 2013 7:173.

\section{Publish with ChemistryCentral and every scientist can read your work free of charge \\ "Open access provides opportunities to our colleagues in other parts of the globe, by allowing anyone to view the content free of charge." \\ W. Jeffery Hurst, The Hershey Company. \\ - available free of charge to the entire scientific community \\ - peer reviewed and published immediately upon acceptance \\ - cited in PubMed and archived on PubMed Central \\ - yours - you keep the copyright \\ Submit your manuscript here: \\ http://www.chemistrycentral.com/manuscript/<smiles>c1ccccc1</smiles> 